\title{
Dialytic peritoneal ultrafiltration versus large volume paracentesis in the treatment of marked ascites in cirrhotic patients
}

\author{
Ali Taha Ali Hassan*,Usama A. Arafa*Mahmoud Kamal El samman*,Mohamed \\ Ibrahim El Sayed* Mohammad Ezzat* \\ *Department of Internal Medicine, Sohag University
}

\begin{abstract}
Background and aim :Ascites in liver cirrhosis is associated with a poor prognosis and impairment of the quality of life.The clinical efficacy and safety of large-volume paracentesis in comparison to dialytic peritoneal ultrafiltration in the treatment of marked ascites were evaluated.

Patients and methods: A total of 96 cirrhotic patients with marked ascites were divided into two groups: group I 48patients treated with dialyticultrafiltration groupIIa 31 patients treated with LVP without albuminand IIb 17 patients treated with LVP plus albumin infusion.

Results:Mean arterial pressure of patients in the studied groups show significant decrease immediately after the different procedures and start to rise within 24 hours and reach readings similar to those before ascites drainage especially with peritoneal ultrafiltration. Improvement in plasma albumin concentration has been reported after dialytic ultrafiltration. There is statistically significant decrease in serum creatinine after 48 hours of the different treatments. The average volume of ascites removed was $(9.04 \pm .04)$ in the dialytic ultrafiltration group versus $(4.45 \pm 0.51)$ in large volume paracentesis without albumin group and $(6.06 \pm 0.83)$ in large volume paracentesis plus albumin infusion. After treatment all patients experienced a relief of ascites which is better with larger amounts of fluids removed as occurred in dialytic ultrafiltration group.

Conclusion:Dialytic ultrafiltration is an effective and relatively safe alternative to largevolume paracentesis in the treatment of marked ascites in cirrhotic patients. Blood pressure is well maintained, kidney functions is preserved. Dialytic ultrafiltration has the advantages of cost and time saving and avoidance of blood-borne infection associated with intravenous transfusion of blood products such as albumin.
\end{abstract}

Key words: Ascites, dialytic ultrafiltration, large volume paracentecis

\section{Introduction}

Ascites is one of the most frequent complications to cirrhosis and portal hypertension. Up to $66 \%$ of cirrhotic patients will develop ascites within a 10 years follow-up period [1]. A cirrhotic patient will only develop ascites if portal hypertension is present and the progression of the disease is closely related to the ability to excrete sodium and free water with the urine [2, 3]. Presence of ascites is a severe

complication of the disease that significantly affects the prognosis and increases the risk of developing other complications such as refractory ascites, spontaneous bacterial peritonitis (SBP), hepato-renal syndrome (HRS) and hyponatremia[4, 5, 6]. The five years 
survival after the diagnosis of ascites has remained poor and ranges between 30$40 \%$.

The approach for the treatment of ascites depends on the grade of ascites. According to the International Ascites Club, ascites is classified into three grades according to the severity of ascites [7].

Lines of Treatment include dietary sodium restriction, diuretics, single large volume paracentesis, serial therapeutic paracentesis, transjugular intrahepatic portosystemic stents (TIPS) and Peritoneovenous shunts.

Therapeutic paracentesis has become the first line of treatment for patients with tense (i.e., grade 3 ) and refractory ascites $[8,9,10]$.

Large-volume paracentesis (LVP) is faster and less likely to exert unwanted side effects than diuretics. One drawback of LVP without adjunctive treatment is the associated risk of post paracentesis circulatory dysfunction (PCD). The most effective method to preventing circulatory dysfunction after LVP is the administration of albumin.

Although TIPS is effective and prevents recurrence in patients with refractory ascites the disadvantages of this technique which include hepatic encephalopathy, high cost and lack of availability in some centers limit its use. The main complication of TIPS is the development of hepatic encephalopathy which is more reported with TIPS than with repeated large volume paracentesis[11, 12].Other complications include shunt thrombosis and stenosis. Uncovered stents are complicated by stenosis in up to approximately $80 \%$ of cases [13].

Despite better control of ascites in patients undergoing TIPS, there was no survival advantage in TIPS in addition to increased morbidity due to hepatic encephalopathy and deterioration of liver function.

Extracorporeal ultrafiltration of ascitic fluid (EUA), which is a technique to reinject concentrated ascites continuously by using a dialyser and pump for haemodialysis, is another available means of treating refractory ascites which was first reported by [14].

Few clinical trials compared the clinical efficacy and safety of large-volume paracentesis and dialytic peritoneal ultrafiltration in the treatment of ascites in cirrhotic patients. The studies concluded that the procedure (dialytic ultrafiltration) was cost-effective with less side effects but needs to be further evaluated on large numbers of patients [15].

\section{Patients and methods}

All patients admitted with cirrhosis and marked ascites in Internal Medicine Department or visit the outpatient clinic during (1-11-2016 up to 1-7-2017) will undergo the following and divided in to 2 groups.

Exclusions criteria:Respiratory, cardiac or renal failure, Non cirrhotic ascites, Gastrointestinal bleeding in the preceding 3 weeks, Spontaneous bacterial peritonitis, Hepatic encephalopathy grade 3 or 4 , presence of hepatocellular carcinoma, hemodynamic instability, Abdominal wall infection, Severe thrombocytopenia (platelet count $<20 \times 103 / \mu \mathrm{L}$ ) or INR > 2.0.

Ethical consideration: The study protocol will be approved by the Ethics committee of Sohag Faculty of Medicine. Written informed consent will be obtained from all participants

Methods:

1- Clinical and laboratory evaluation: History taking, physical examination. and Laboratory investigations including 
SOHAG MEDICAL JOURNAL

Vol. 23 No.2 Apr2019

CBC, Renal, liver functions, blood electrolytes, analysis of the peritoneal fluid and abdominal ultrasonography.

2-Cirrhotic subjects with marked ascites were randomly allocated to either continuous paracentesis and albumin infusion $(8 \mathrm{gm} / \mathrm{L}$ drained ascites with an expected paracentesis volume of $>5$ litre) or dialytic ultrafiltration (Ascites will be removed via a peritoneal catheter and ultrafiltered using a hemodialyzer.
Dialytic peritoneal ultrafiltration versus large volume Mohamed Ibrahim El Sayed.et al

The concentrate continuously returned to the peritoneal space.

4- Recording the complication during each procedure or shortly after (48 hours): Renal disturbance (renal functions), vascular disturbance (hypotension), encephalopathy, abdominal pain, fever, cramps, local infection or hematoma.

5- Comparing the cost and time of different procedures.

\section{Results}

This study included 96 patients with liver cirrhosis and marked ascites at Sohag University Hospitals at the period between (1-11-2016 up to 1-7-2017) in Internal Medicine Department or visit the outpatient clinic divided in to 2 groups.Group I: Included 48 patients with liver cirrhosis and marked ascites treated with dialytic ultrafiltration.Group II: included 2 sub-groups:Group IIa: Large volume paracentecis without albumin infusion group include 31 patients.Group IIb:Large volume paracentecis plus albumin infusion group include 17 patients.

\begin{tabular}{|c|c|c|c|c|}
\hline Patients characteristics & $\begin{array}{l}\begin{array}{l}\text { Peritoneal } \\
\text { ultrafiltrtion } \\
\text { group }(1)\end{array} \\
48 \text { patients }\end{array}$ & $\begin{array}{l}\text { Large } \\
\text { paracentecis }\end{array} \begin{array}{l}\text { volume } \\
\text { without } \\
\text { albumin group(IIa) } \\
\text { 31 patients }\end{array}$ & $\begin{array}{lr}\text { Large } & \text { volume } \\
\text { paracentecis } & \text { with } \\
\text { albumin group } & \\
\text { (IIb) } & \\
\text { 17 patients } & \\
\end{array}$ & $\begin{array}{l}P \\
\text { value }\end{array}$ \\
\hline $\begin{array}{l}\text { Age } \\
\text { Mean } \pm \text { S.D. } \\
\text { Median (Range) }\end{array}$ & $\begin{array}{l}54.89 \pm 7.11 \\
55(39-70)\end{array}$ & $\begin{array}{l}58.09 \pm 5.33 \\
56(51-67)\end{array}$ & $\begin{array}{l}54.94 \pm 6.99 \\
56(43-66)\end{array}$ & 0.09 \\
\hline $\begin{array}{l}\text { Male } \\
\text { Female }\end{array}$ & $\begin{array}{ll}38 & 79.2 \% \\
10 & 20.8 \%\end{array}$ & $\begin{array}{ll}19 & 61.3 \% \\
12 & 38.7 \%\end{array}$ & $\begin{array}{ll}9 & 52.9 \% \\
8 & \mathbf{4 7 . 1 \%}\end{array}$ & 0.074 \\
\hline $\begin{array}{l}\text { Liver cirrhosis etiology: } \\
\text { Hepatitis C virus } \\
\text { Hepatitis B virus } \\
\text { Others }\end{array}$ & $\begin{array}{ll}36 & 75 \% \\
9 & 18.8 \% \\
3 & 6.2 \% \\
\end{array}$ & $\begin{array}{ll}23 & 74.2 \% \\
6 & 19.4 \% \\
2 & 6.5 \% \\
\end{array}$ & $\begin{array}{ll}13 & \mathbf{7 6 . 5 \%} \\
3 & 17.6 \% \\
1 & 5.9 \%\end{array}$ & 1 \\
\hline $\begin{array}{l}\text { Ascites duration: } \\
\text { Less than } 6 \text { months } \\
\text { More than } 6 \text { months }\end{array}$ & $\begin{array}{ll}22 & 45.8 \% \\
26 & 54.2 \%\end{array}$ & $\begin{array}{ll}19 & 61.3 \% \\
12 & 38.7 \%\end{array}$ & $100 \%$ & $<0.001$ \\
\hline Lower limb edema: & $64.6 \%$ & $38.7 \%$ & $100 \%$ & $<0.001$ \\
\hline Previous paracentecis: & $43.8 \%$ & $45.2 \%$ & $41.2 \%$ & 0.965 \\
\hline 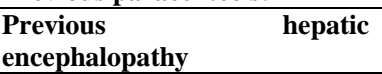 & $18 \quad 37.5 \%$ & $29 \%$ & $29.4 \%$ & 0.687 \\
\hline Systemic hypertension: & $31.2 \%$ & $6.5 \%$ & $35.3 \%$ & 0.02 \\
\hline Diabetes mellitus: & $16.7 \%$ & $19.4 \%$ & $35.3 \%$ & 0.259 \\
\hline Hepatic encephalopathy: & $4 \quad 8.3 \%$ & $6.5 \%$ & $5.9 \%$ & 0.923 \\
\hline $\begin{array}{l}\text { Systolic blood pressure } \\
\text { Mean } \pm \text { S.D. }\end{array}$ & $130.2 \pm 11.8$ & $132.5 \pm 4.4$ & $131.4 \pm 7.2$ & 0.835 \\
\hline $\begin{array}{l}\text { Diastolic blood pressure } \\
\text { Mean } \pm \text { S.D. }\end{array}$ & $81.3 \pm 8.04$ & $81.9 \pm 4.4$ & $78.5 \pm 2.9$ & 0.097 \\
\hline $\begin{array}{l}\text { Mean arterial blood pressure } \\
\text { Mean } \pm \text { S.D. }\end{array}$ & $97.5 \pm 9.05$ & $98.75 \pm 4.19$ & $96.1 \pm 3.05$ & 0.225 \\
\hline $\begin{array}{l}\text { Serum albumin }(\mathrm{g} / \mathrm{dL}) \\
\text { Mean } \pm \text { S.D. }\end{array}$ & $2.4 \pm 0.31$ & $2.37 \pm 0.28$ & $2.42 \pm 0.17$ & 0.766 \\
\hline $\begin{array}{l}\text { Serum creatinine }(\mathrm{mg} / \mathrm{dL}) \\
\text { Mean } \pm \text { S.D. }\end{array}$ & $1.09 \pm 0.09$ & $1.05 \pm 0.07$ & $1.12 \pm 0.11$ & 0.052 \\
\hline $\begin{array}{l}\text { Child- Pugh Class } \\
\text { B } \\
\text { C }\end{array}$ & $\begin{array}{ll}9 & 18.8 \% \\
39 & 81.2 \%\end{array}$ & $\begin{array}{ll}9 & 29 \% \\
22 & 71 \%\end{array}$ & $\begin{array}{ll}2 & 11.8 \% \\
15 & 82.2 \%\end{array}$ & 0.327 \\
\hline $\begin{array}{l}\text { MELD score* } \\
\text { Mean } \pm \text { S.D. } \\
\text { Median (Range) }\end{array}$ & $\begin{array}{l}14.06 \pm 2.76 \\
14(9-18)\end{array}$ & $\begin{array}{l}12 \pm 2.78 \\
12(7-17)\end{array}$ & $\begin{array}{l}15.53 \pm 2.67 \\
15(11-19)\end{array}$ & $<0.001$ \\
\hline
\end{tabular}


SOHAG MEDICAL JOURNAL

Vol. 23 No.2 Apr2019
Dialytic peritoneal ultrafiltration versus large volume Mohamed Ibrahim El Sayed.et al

Table 1: Compare the demographic, clinical and laboratory characteristics of the studied groups

*MELD score (Model for End -Stage Liver Disease)

\begin{tabular}{|c|c|c|c|c|c|}
\hline Parameter & $\begin{array}{l}\text { MAP before the } \\
\text { procedure }\end{array}$ & $\begin{array}{l}\text { MAP immediately } \\
\text { after procedure }\end{array}$ & $\begin{array}{l}\text { MAP pressure } 24 \mathrm{~h} \\
\text { after procedure }\end{array}$ & $\begin{array}{l}\text { MAP } 48 \text { h after } \\
\text { procedure }\end{array}$ & P-value \\
\hline \multicolumn{6}{|c|}{ Peritoneal ultrafiltration } \\
\hline Mean \pm S.D. & $97.59 \pm 9.05$ & $88.77 \pm 6.78$ & $92.59 \pm 7.72$ & $97.52 \pm 8.24$ & $<0.001^{*}$ \\
\hline \multicolumn{6}{|c|}{ large volume paracentesis without albumin } \\
\hline Mean \pm S.D. & $98.75 \pm 4.19$ & $90.6 \pm 5.02$ & $92.14 \pm 4.61$ & $95.07 \pm 2.47$ & $<0.001 *$ \\
\hline \multicolumn{6}{|c|}{ large volume paracentesis plus albumin infusion } \\
\hline Mean \pm S.D. & $96.15 \pm 3.05$ & $87.02 \pm 2.62$ & $88.42 \pm 2.68$ & $96.25 \pm 3.05$ & $<0.001^{*}$ \\
\hline
\end{tabular}

Table 2: Comparison of repeated measurements of the mean arterial blood pressure of patients in the studied groups

There is high statistically significant difference ( $\mathrm{p}$-value $<0.001)$ between the studied groups as regard theMean Arterial Blood pressure (MAP).

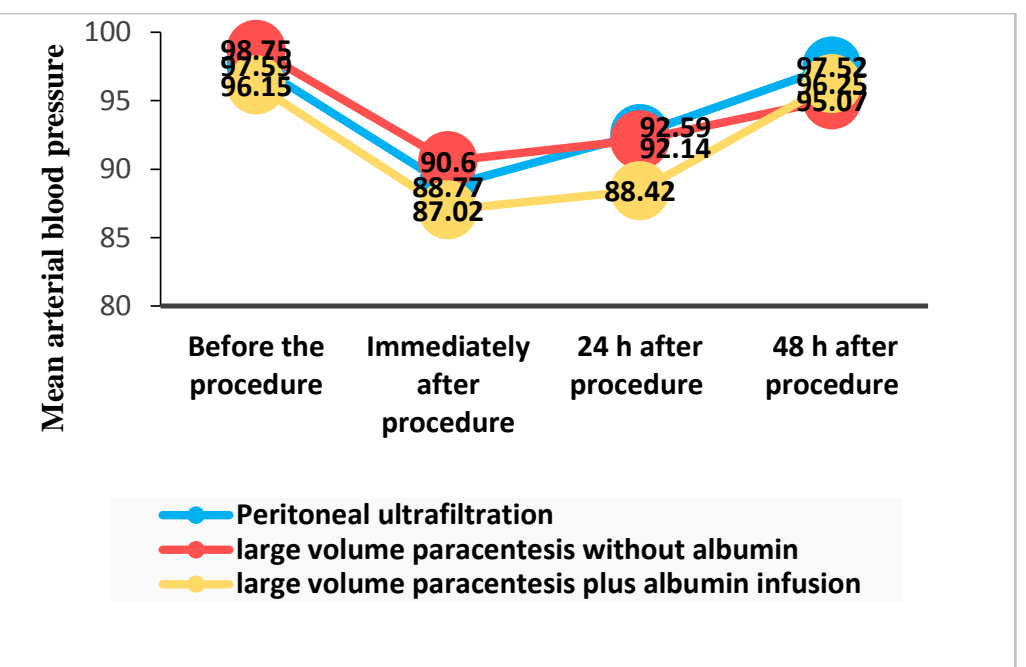

Figure 1: Comparison of repeated measurements of the MAP of patients in the studied groups

Mean arterial pressure of patients in the studied groups show significant decrease immediately after the different procedures and start to rise within 24 hours and reach readings similar to those before ascites drainage especially with peritoneal ultrafiltration. 
SOHAG MEDICAL JOURNAL

Vol. 23 No.2 Apr2019
Dialytic peritoneal ultrafiltration versus large volume Mohamed Ibrahim El Sayed.et al

\begin{tabular}{|l|l|l|l|l|l|l|l|}
\hline Parameter & group I & Group IIa & Group IIb & P-value & P1 & P2 & P3 \\
\hline $\begin{array}{l}\text { Serum albumin } \\
\text { before } \\
\text { Mean } \pm \text { S.D. }\end{array}$ & $2.4 \pm 0.31$ & $2.37 \pm 0.28$ & $2.42 \pm 0.17$ & 0.766 & 0.506 & 0.618 & 0.991 \\
\hline $\begin{array}{l}\text { Creatinine before } \\
\text { Mean } \pm \text { S.D. }\end{array}$ & $1.09 \pm 0.09$ & $1.05 \pm 0.07$ & $1.12 \pm 0.11$ & 0.052 & 0.06 & 0.326 & 0.028 \\
\hline $\begin{array}{l}\text { Serum albumin } \\
\text { after } \\
\text { Mean } \pm \text { S.D. }\end{array}$ & $2.59 \pm 0.28$ & $2.39 \pm 0.24$ & $2.71 \pm 0.19$ & $<0.001$ & 0.001 & 0.173 & $<0.001$ \\
\hline $\begin{array}{l}\text { Creatinine after } \\
\text { Mean } \pm \text { S.D. }\end{array}$ & $1.01 \pm 0.1$ & $0.96 \pm 0.11$ & $1.08 \pm 0.09$ & 0.003 & 0.075 & 0.017 & 0.001 \\
\hline
\end{tabular}

Table 3:Comparison of serum albumin $(\mathrm{g} / \mathrm{dL})$ and Creatinine $(\mathrm{mg} / \mathrm{dl})$ of patients in the groups before and after the procedure

$\mathbf{P}$ value compared the three groupsP1 compared peritoneal ultrafiltration (group I) and LVP without albumin (groupIIa)

P2 compared peritoneal ultrafiltration (group I) and LVP plus albumin infusion groups (groupIIb)

P3 compared LVP without albumin (groupIIa) and LVP plus albumin infusion (groupIIb)groups

There is statistically significant difference (p-value $<0.05)$ betweenthe studied groups as regard serum albumin and creatinine after the procedures.

\begin{tabular}{|c|c|c|c|c|c|}
\hline parameter & group I & Group IIa & Group IIb & Total & $P$ value \\
\hline $\begin{array}{l}\text { Liters removed } \\
\text { Mean } \pm \text { S.D. } \\
\text { Median (Range) }\end{array}$ & $\begin{array}{l}9.04 \pm 9.04 \\
9(7-13)\end{array}$ & $\begin{array}{l}4.45 \pm 0.51 \\
4(4-5)\end{array}$ & $\begin{array}{l}6.06 \pm 0.83 \\
6(5-7)\end{array}$ & $\begin{array}{l}7.03 \pm 2.43 \\
7(4-13)\end{array}$ & $<0.001$ \\
\hline $\begin{array}{l}\text { Time of procedure } \leq 3 \text { hours } \\
\text { Time of procedure }>3 \text { hours }\end{array}$ & $\begin{array}{ll}33 & 68.8 \% \\
15 & 31.2 \%\end{array}$ & $\begin{array}{ll}5 & 16.1 \% \\
26 & 83.9 \%\end{array}$ & $\begin{array}{ll}3 & 17.6 \% \\
14 & 82.4 \%\end{array}$ & $\begin{array}{ll}\mathbf{4 1} & \mathbf{4 2 . 7 \%} \\
\mathbf{5 5} & \mathbf{5 7 . 3 \%}\end{array}$ & $<0.001$ \\
\hline $\begin{array}{l}\text { Encephalopathy within } 48 \text { h after } \\
\text { procedure }\end{array}$ & $\begin{array}{ll}0 & \mathbf{0 . 0 \%}\end{array}$ & $\begin{array}{ll}6 & 19.4 \%\end{array}$ & $0.0 \%$ & $6 \quad 6.2 \%$ & 0.001 \\
\hline $\begin{array}{l}\text { Post procedure fever or infection at } \\
\text { cannula site }\end{array}$ & 0 & 0 & $\mathbf{0}$ & $\mathbf{0}$ & NA \\
\hline Post procedure abdominal pain & $18.8 \%$ & $16.1 \%$ & $17.6 \%$ & $1717.7 \%$ & 0.957 \\
\hline
\end{tabular}

Table 4:Comparison between the studied groups regarding time of procedure, liters removed and post procedure complications

NA (not applicable)

As regard time of procedure and liters removed there is high statistically significant difference ( $\mathrm{p}$-value < 0.001) between the studied groups. There is no statistically significant difference between the studied groups as regard post procedure fever, abdominal pain and infection at cannula site.

\section{Discussion}

In this study, we evaluate the efficacy of peritoneal ultrafiltration using the heamodialysis filter and machine as a treatment of marked ascites in cirrhotic patients and identify the benefits and 
complications in comparison to large volume paracentesis.In this study, patients of both groups showed a significant decrease of the Blood Pressure immediately after treatment and start to recover after 24 hours and reach levels similar to those before the procedure after 48 hours mainly in dialytic ultrafiltration group.

In this study comparing the measurements of the Blood Pressure before, 1 hour after, 24 hours and 48 hours after for each procedure was statistically significant. Comparison between the studied groups regarding repeated measurements of Mean Arterial Blood Pressure 24 hours after the procedure show significant $p$ value.

In the current study, there was a significant reduction in the MAP after LVP. Similar to this finding, GarciaCompeanet al., 2002;Appenrodtet al., 2008; Umgelteret al., 2008 found a significant decrease in the MAP 1 and 24 $\mathrm{h}$ after paracentesis compared with that before paracentesis. Furthermore, Phillip et al., 2014 showed a decrease in the MAP and the systemic vascular resistance immediately, $2 \mathrm{~h}$ after and $6 \mathrm{~h}$ after paracentesis. This decrease in MAP is probably due to a decreased intravascular volume as a result of rapid reformation of ascites.

Dialytic ultrafiltration and peritoneal reinfusion does not adversely affect hemodynamic despite the rapid removal of a large volume of ascitic fluid this was in agreement withBernardi $M$ et al., 1994; Borzio $M$ et al., 1995; Parbhoo SP et al., 1974; Raju SF et

al., 1984; Lai KN et al., 1987. It may be related to ascetic fluid removal while preserving protein and intra-abdominal albumin is back flow to the blood and maintain the intravascular volume. The concentrated proteins were reabsorbed into the systemic circulation making it possible to exert less influence into the systemic circulation and blood pressure. In the current study improvement in plasma albumin concentration has been reported after dialytic ultrafiltration. This was in agreement with Raju $\mathbf{S}$ et al., 1984; Lai KN et al., 1987. Also improvement in plasma albumin concentration has been reported after large volume paracenecis plus intravenous albumin infusion but not after paracenecis without intravenous albumin infusion. In peritoneal ultrafiltration fluids are removed and concentrated proteins are returned back to the peritoneal cavity to be reabsorbed. In the current study there is statistically significant decrease in serum creatinine after 48 hours of the different treatments. The mechanisms for the improvement or stabilization of renal function remain to be defined. A possible mechanism is a transient increase in the effective intravascular volume due to lymphatic reabsorption of albumin from ascites after reduction of the intraperitoneal volume [23, 24].In fact, protein concentrations in ascites increased significantly in many studies $[\mathbf{2 0}, 21,24,25]$ Furthermore, the increase of the ascitic protein concentration may contribute to the very low complication rate of the procedure. Against this was a significant

increase in plasma creatinine was also noted 48 hours after paracentesis in the study of (Kao et al., 1985).

(Garcia-Compeanet al., 2002) reported that there was no significant difference in serum creatinine before and $24 \mathrm{~h}$ after LVP. Also, (Maslovitz et al., 2004)reported no significant difference in serum creatinine before and after paracentesis. In contrast, results of the 
present study showed a significant reduction in serum creatinine $48 \mathrm{~h}$ after LVP. Similar findings were observed by (Savino et al., 1988), who showed a significant decrease in serum creatinine after paracentesis. The decrease in serum creatinine attributed to the increased cardiac output due to increased cardiac compliance after paracentesis and the decreased intra-abdominal pressure improved renal perfusion by lowering venous and retroperitoneal pressures (Umgelter A et al., 2008) as the impairment of renal function caused by direct renal compression due to increased intra-abdominal pressure. These events might be the reason for the improvement in renal perfusion and in serum creatinine as a consequence [28].

In the current study none of patients developed hepatic encephalopathy within 48 hours after dialytic ultrafiltration or large volume paracentesis plus albumin infusion groups in comparison to occurrence of encephalopathy to 6 cases $(19.4 \%)$ in the group of large volume paracentesis without albumin infusion this was high significant statistically. This may be benefit of albumin which increases in the serum after dialytic ultrafiltration or large volume paracentesis plus albumin infusion. The average volume of ascites removed was $(9.04 \pm .04)$ in the dialytic ultrafiltration group versus $(4.45 \pm 0.51)$ in large volume paracentesis without albumin group and $(6.06 \pm 0.83)$ in large volume paracentesis plus albumin infusion. After treatment all patients experienced a relief of ascites which is better with larger amounts of fluids removed as occurred in dialytic ultrafiltration group.The treatment duration was significantly short with dialytic ultrafiltration group in comparison to large volume paracentesis in spite of more liters removed by dialytic ultrafiltration. This is in agreement with Lai KN et al., 1991. With shorter duration of procedurs time spent in hospital and patients compliance will be better.In the current study within 48 hours of different procedures no febrile episode or infection at sites of cannulation was noted. The cost of dialytic ultrafiltration is about 250 Egyptian pounds and that of albumin used in large volume paracentesis plus albumin infusion is 550 pounds for each 10 grams of albumin which is relatively expensive.

\section{Conclusion}

Dialytic ultrafiltration is an effective and relatively safe alternative to largevolume paracentesis plus intravenous albumin infusion in the treatment of massive ascites in cirrhotic patients.Blood pressure is well maintained, kidney functions is preserved. Dialytic ultrafiltration has the advantages of cost and time saving and avoidance of blood-borne infection associated with intravenous transfusion of blood products such as albumin.

\section{References}

1. Gines $\mathrm{P}$ and Cardenas A. The management of ascites and hyponatremia in cirrhosis. Semin Liver Dis 2008;28:4358.

2. Møller S and Henriksen JH. The systemic circulation in cirrhosis. I: Gines P, Arroyo V, Rodes J, Schrier RW red. Ascites and renal dysfunction in liver disease. 2nd ed. Malden: Blackwell, 2005:139-155.

3. Ripoll C, Groszmann R, Garcia-Tsao G, et al. Hepatic venous pressure gradient predicts clinical decompensation in patients with compensated cirrhosis. Gastroenterology 2007;133:481-8.

4. Guevara M, Cárdenas A, Uriz J, et al. "Prognosis in patients with cirrhosis and ascites," in Ascites and Renal 
Dysfunction in Liver Disease, P. Ginès, V. Arroyo, J. Rodés, and R. W. Schrier, Eds., pp. 260-270, Blackwell, Malden, Mass, USA, 2005.

5. Møller S, Henriksen JH and Bendtsen F. Ascites: Pathogenesis and therapeutic principles. ScandJGastroenterol 2009;110.

6. Khan J, Pikkarainen P, Karvonen AL, et al. Ascites: Aetiology, mortality And the prevalence Of spontaneous bacterial peritonitis. Scand J Gastroenterol 2009;44(8):970- 4.

7. Moore KP, Wong F, Gines P, etal.The management of ascites in cirrhosis: Report on the consensus conference the International Ascites Club. Hepatology. 2003;38(1):258-266

8. Moore KP and Aithal GP. Guidelines on the management of ascites in cirrhosis. Gut 2006;55 (Suppl 6):1-12.

9. Runyon BA. Management of adult patients with ascites due to cirrhosis: an update. HEPATOLOGY 2009;49:20872107.

10.Gine`s P, Angeli P, Lenz K, et al. EASL clinical practice guidelines on the management of ascites, spontaneous bacterial peritonitis, and hepatorenal syndrome in cirrhosis. $\mathrm{J}$ Hepatol 2010;53:397-417.

11.Saab S, Nieto JM, Lewis SK, et al. TIPS versus paracentesis for cirrhotic patients with refractory ascites. The Cochrane Database of Systematic Reviews. 2006;(4):CD004889 .

12. Salerno $\mathrm{F}$, Cammà $\mathrm{C}$, Enea $\mathrm{M}$, et al. Transjugular intrahepatic portosystemic shunt for refractory ascites: A meta-analysis of individual patient data. Gastroenterology. 2007;133(3):825-834.

13. Boyer TD and Haskal ZJ, D. American Association for the Study of Liver. The role of transjugular intrahepatic portosystemic shunt in the management of portal hypertension. Hepatology. 2005;41(2):386-400.

14. Hariprasad MK, Paul PK, Eisinger RB, et al. Extracorporeal dialysis of ascites. A new technique. Arch Intern Med 1981; 141: 1550-1551.
15.Lai KN, Li P, Law E, et al. Large-volume paracentesis versus dialytic ultrafiltration in the treatment of cirrhotic ascites. Q J Med 1991; 78:33-41.

16. García-Compean D, Blanc P, Larrey D, et al. Treatment of cirrhotic tense ascites with Dextran-40 versus albumin associated with large volume paracentesis: a randomized controlled trial. Ann Hepatol 2002; 1:29-35.

17. Appenrodt B, Wolf A, Grünhage F, et al. Prevention of paracentesis-induced circulatory dysfunction: midodrinevs albumin. A randomized pilot study. Liver Int 2008; 28:1019-1025.

18.Umgelter A, Reindl W, Wagner KS, et al. Effects of plasma expansion with albumin and paracentesis on haemodynamics and kidney function in critically ill cirrhotic patients with tense ascites and hepatorenal syndrome: a prospective uncontrolled trial. Crit Care 2008; 12:R4.

19.Phillip V, Saugel B, Ernesti C, et al. Effeects of paracentesis on hemodynamic parameters and respiratory function in critically ill patients. BMC Gastroenterol 2014; 14:18.

20.Bernardi M, Rimondi A, Gasbarrini A, et al. Ascites apheresis, concentration and reinfusion for the treatment of massive or refractory ascites in cirrhosis. J Hepatol 1994; 20:289 -295.

21.Borzio M, Romagnoni M, Sorgato G, et al. A simple method for ascites concentration and reinfusion. Dig Dis Sci 1995;40:1054- 1059.

22.Parbhoo SP, Ajdujiewicz A and Sherlock S. Treatment of ascites by continuous ultrafiltration and reinfusion of protein concentrate. Lancet 1974; 1: 949-952.

23.Raju SF and Achord JL. The efects of dialytic ultrafiltration and peritoneal reinfusion in the management of diuretic resistantascites. Am J Gastroenterol 1984; 79: 308-312.

24.Lai KN, Leung JW and Vallance-Owen J. Dialytic ultrafiltration by hemofilter in treatment of patients with refractory ascites and renal insufficiency. Am $\mathrm{J}$ Gastroenterol 1987; 82:665- 668. 
SOHAG MEDICAL JOURNAL

Vol. 23 No.2 Apr2019

25. Cadranel JF, Grippon P, Gargot D, et al. Simultaneous dialytic ultrafiltration and intraperitoneal reinfusion in cirrhotic patients with intractable ascites.Preliminary results of a comparative study versus large paracentesis. J Hepatol.1992; 15:271272.

26.Kao HW, Rakov NE, Savage E, et al. The effect of large volume paracentesis on plasma volume a cause of hypovolemia? Hepatology 1985; 5: 403407.
Dialytic peritoneal ultrafiltration versus large volume Mohamed Ibrahim El Sayed.et al

27. Maslovitz S, Jaffa A, Eytan O, et al. Renal blood flow alteration after paracentesis in women with ovarian hyperstimulation. ObstetGynecol 2004; 104:321-326.

28. Savino JA, Cerabona T, Agarwal N, et al. Manipulation of ascitic fluid pressure in cirrhotic to optimize hemodynamic and renal function. Ann Surg 1988; 208:504511. 